Original Article

Received/Accepted Dates

10.10.2021/01.11.2021

DOI $\quad 10.52096 /$ jsrbs.6.1.7.13.33
Journal of Social Research and Behavioral Sciences

Sosyal Araştırmalar ve Davranış Bilimleri Dergisi

ISSN:2149-178X

Volume: 7 Issue: 13 Year: 2021

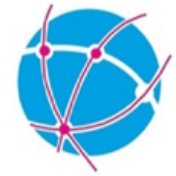

\section{Yetişkinlerde Erken Dönem Uyum Bozucu Şemalar Bilişsel Esneklik ve Bilişsel Duygu Düzenleme Arasındaki İlişkiler}

Klinik Psikolog Muhammed USLUCA

klinikpsimusluca@gmail.com

ORCİD NO: 0000-0002-6167-3837

Dr. Öğr. Üyesi Kahraman GÜLER

İstanbul Aydın Üniversitesi

Fen-Edebiyat Fakültesi

kahramanguler@aydin.edu.tr

ORCID NO: 0000-0002-0049-0658

\title{
Özet
}

$\mathrm{Bu}$ çalışma; erken dönem uyum bozucu şemalar, bilişsel esneklik ve bilişsel duygu düzenleme arasındaki ilişkilerin incelenmesi amacıyla yapılmıştır. Araştırmaya İstanbul'da yaşayan 252'si kadın, 91'i erkek olmak üzere 18 yaş üstü toplamda 343 kişi katılım göstermiştir. Araştırmada sosyodemografik veri fomu, Young Şema Ölçeği Kısa Form-3 (YŞÖ-KF3), Bilişsel Esneklik Ölçeği (BEÖ) ve Bilişsel Duygu Düzenleme Ölçeği (BDDÖ) kullanılmıştır. Veri toplama araçlarının uygulanabilmesi için sosyodemografik veri formu, Young Şema Ölçeği Kısa Form-3, Bilişsel Esneklik Ölçeği ve Bilişsel Duygu Düzenleme Ölçeği kağıda bastırılmış ve basit seçkisiz yöntemle seçilmiş 18 yaş üstündeki 343 katılımcıya dağıtılmıştır. İki veya daha fazla değişken arasındaki ilişki için Pearson Korelasyon analizi uygulanmıştır. Araştırma sonucunda Bilişsel Esneklik Ölçeği ile duygusal yoksunluk, sosyal izolasyon, güvensizlik, kusurluluk, duyguları bastırma, iç içe geçme, bağımlılık, terk edilme, dayanıksızlık, başarısızlık, karamsarlık şemaları arasında negatif yönlü bir ilişki elde edilmiştir. Bilişsel Esneklik Ölçeği ile bilişsel duygu düzenlemenin alt boyutarı olan; plana tekrar odaklanma, pozitif yeniden gözden geçirme, bakış açısına yerleştirme puanları arasında pozitif ilişki bulunmuştur. Kendini suçlama, yıkım, diğerlerini suçlama puanları arasında ise negatif ilişki tespit edilmiştir. Bilişsel duygu düzenlemenin alt boyutları ile şemalar arasındaki ilişkilere 
bakıldığında ise bulguların büyük kısmında; bilişsel duygu düzenlemenin uyumsuz alt boyutları ile şemalar arasında pozitif yönlü ilişki bulunurken, uyumlu alt boyutları ile şemalar arasında negatif yönlü ilişki bulunmuştur.

Anahtar Kelimeler: Şema, bilişsel duygu düzenleme, bilişsel esneklik

\title{
Relationships Between Early Maladaptive Schemas Cognitive Flexibility and Cognitive Emotion Regulation in Adults
}

\begin{abstract}
This work; It was conducted to examine the relationships between early maladaptive schemas, cognitive flexibility and cognitive emotion regulation. A total of 343 people over the age of 18, 252 women and 91 men, living in Istanbul participated in the study. Sociodemographic data form, Young Schema Scale Short Form-3 (YSS-SF3), Cognitive Flexibility Scale (CFS) and Cognitive Emotion Regulation Scale (CERS) were used in the study. In order to apply the data collection tools, the sociodemographic data form, Young Schema Scale Short Form-3, Cognitive Flexibility Scale and Cognitive Emotion Regulation Scale were printed on paper and distributed to 343 participants over the age of 18 selected by simple random method. Pearson Correlation analysis was used for the relationship between two or more variables. As a result of the research, a negative relationship was found between the Cognitive Flexibility Scale and emotional deprivation, social isolation, insecurity, imperfection, suppression of emotions, intertwining, addiction, abandonment, endurance, failure, and pessimism. The sub-dimension of cognitive emotion regulation with the Cognitive Flexibility Scale; A positive correlation was found between the scores of focusing on the plan, positive reviewing, and placing in perspective. A negative correlation was found between the scores of self-blame, destruction, and blaming others. When we look at the relationships between the subdimensions of cognitive emotion regulation and the schemas, in most of the findings; While there was a positive correlation between the maladaptive sub-dimensions of cognitive emotion regulation and the schemas, a negative relationship was found between the congruent sub-dimensions and the schemas.
\end{abstract}

Keywords: Schema, cognitive emotion regulation, cognitive flexibility

\section{Giriş}

Bilişsel davranışçı terapi özellikle 80'li yıllardan beri klinikte en fazla kullanılan, üzerine çok araştırma yapılan ve yüz güldürücü sonuçlar elde edilen bir psikoterapi ekolüdür (Johnsen ve 
Friborg, 2015, s.1). Bilişsel davranışçı terapi, özellikle eksen I bozuklukları için oldukça verimli olmasına rağmen eksen II bozukluklarında aynı başarıyı gösteremediği fark edilmiş ve yeni bir terapi ekolü ortaya koyma ihtiyacı belirmiştir (Ertürk ve Kaynar, 2017, s.98; Türkçapar, 2018:78). $\mathrm{Bu}$ amaç doğrultusunda 90'lı yıllarda Young ve çalışma arkadaşları "şema terapi” adında bir terapi oluşturmuşlardır. Şema terapi, bireylerin erken dönem uyum bozucu şemalarını, uyumsuz başa çıkma stillerini ve modlarını değişime uğratarak bireyin karşılanamamış temel ihtiyaçlarına ulaşmasına yol açan bir terapi modelidir (Young, Klosko ve Weishaar, 2019).

Şema terapi açısından bakıldığında, evrensel olarak tüm insanlar dünyaya çeşitli duygusal ihtiyaçlar ile gelmektedir. Bu ihtiyaçlar yeteri kadar tatmin edilemediğinde ya da aşırı şekilde doyurulmaya çalışıldığında bireyde uzun yıllar devam edecek, kökleşmiş yapılar olan şemalar ve şema alanları ortaya çıkmaktadır. Bu ihtiyaçlar; güvenli bağlanma, bağımsızlık, duygularını ve ihtiyaçlarını ifade etme, kendiliğindenlik ve oyun, makul sınırlar olarak sıralanabilir (Young vd., 2019, s.31).

Temel duygusal ihtiyaçlar yeteri kadar doyurulmadığında ya da aşırı doyurulmaya çalışıldığında ortaya çıkan şemalar 5 alt alan ve 18 şema olarak tanımlanmıştır (Güler ve Gümüş, 2018, s.381). $\mathrm{Bu}$ alt alanlar ve şemalar şu şekildedir;

1. Kopukluk ve Reddedilme Alanı

- Terk edilme

- Güvensizlik/Kötüye Kullanılma

- Duygusal Yoksunluk

- Kusurluluk/Utanç

- Sosyal İzolasyon/Yabancılaşma

2. Zedelenmiş özerklik ve Performans Alanı

- Bağımlılık/Yetersizlik

- Hastalıklar ve Zarar Görme Karşısında Dayanıksızlık

- İç İçe Geçme/Gelişmemiş Benlik

- Başarısızlık 


\section{Zedelenmiş Sınırlar Alanı}

- Haklılık/Üstünlük

- Yetersiz Öz-denetim/Öz-disiplin

4. Başkaları Yönelimlilik Alanı

- Boyun Eğicilik

- Kendini Feda

- Onay Arayıc1lık

5. Aşırı Uyarılma ve Baskılama Alanı

- Olumsuzluk/Karamsarlık

- Duyguları Baskılama

- Yüksek Standartlar/Aşırı Eleştiricilik

- Cezalandırıcılık (Young vd., 2019, s.36-40).

Terk edilme şeması, olan birey kendisinin bir şekilde terk edileceğine ve bırakılacağına inanmaktadır. Bu şemaya sahip olan bireyler ilişkilerde rahat davranamazlar ve en ufak bir işareti dahi terk edileceğine işaret olarak algılayabilirler (Takebe, 2020, s.3). Duygusal yoksunluk şeması bulunan birey, kendisi ile yeteri kadar ilgilenilmeyeceğine ve sevilmeyeceğine inanmaktadır (Young vd., 2019, s.41). Kusurluluk şeması, bireye kendisinin kötü, çirkin, istenilmeyen birisi olduğu inancını vermektedir. Bu bireylerin kendileri ile ilgili algıları son derece olumsuzdur (Hayes, Harris ve Carver, 2004, s.371). Sosyal izolasyon şemasının kökeni, diğer şemalara göre daha çok ergenlik döneminden köken almaktadır. Bu bireyler kendilerinin temel olarak diğer insanlardan farklı olduğuna inanmakta ve kendisini hiçbir gruba ait olarak hissedememektedir (Kim, Lee ve Lee, 2014, s.138)

Bağımlılık şeması bulunan bireyler, çevresindeki diğer insanlara (özellikle yakın çevresi) "aşırı" bir bağlılık göstermektedir. Onların yardımı olmadan kendisinin günlük işlerini dahi yerine getirmekte zorlanacağı inancını taşımakta ve yaşama tutunabilmek için hep diğer insanların varlığını aramaktadır (Işık, 2019, s.8). Dayanıksızlık şeması, bireyin hastalıklar, felaketler karşısında yetersiz olduğu ve onlarla baş edemeyeceği inancını içermektedir. Bu bireyler başlarına 
kontrol edemeyecekleri, baş edemeyecekleri felaketler geleceği kaygısını fazlası ile hissetmektedir (Young vd., 2019, s.42). İç içe geçmiş benlik şeması bulunan bireyler, kendi kimliklerini adeta başka insanların kimliğinde eritmektedir. Bunun altında diğer insanlarla yapışık ve iç içe olunmazsa bireyin hayata tutunması ve mutlu olmasının çok zor olduğu inancı yatmaktadır (Thimm, 2010, s.374). Başarısızlık şemasına sahip olan bireyler ise ne yaparlarsa yapsınlar kendilerinin eninde sonunda başarısız olacaklarına inanmaktadır. Bu bireyler kendilerini “başarısız” olarak nitelemektedirler (Renner, Arntz ve Leeuw, 2013, s.168).

Haklılık şeması bulunan bireyler, kendilerinin her zaman ve her konuda haklı olduğuna inanmaktadır. Diğer insanların da bazı konularda haklı olabileceğini kabul etmemekte ve diğer insanların haklarına yeteri kadar saygı göstermemektedirler (Hawke ve Provencher ve Parikh, 2013, s.119). Yetersiz öz denetim şemasına sahip olan bireyler ise aşırı derecede dürtüsel davranışlar sergilemektedir. Başkaları için geçerli olan kuralların kendileri için geçerli olmadığı inancı hakimdir (Hawke, Provencher ve Parikh, 2013 s. 120).

Boyun eğicilik şeması bulunan bireyler diğer insanların istediği her şeye "itaat" edercesine boyun eğmektedir. Kendi ihtiyaçlarından, isteklerinden feragat ederek diğer insanların isteklerini yerine getirmeye çalışmaktadırlar (Cecero ve Young, 2001, s.219). Kendini feda şeması boyun eğicilik şemasına benzemekle beraber farklı şemalardır. Boyun eğicilik şemasındaki birey, karşı taraftan bir zarar göreceği endişesiyle ya da "sorun" çıkmaması için bunu yaparken, kendini feda şemasındaki birey gerçekten kendini diğer insanlara feda etmeyi istemekte ve bunu yaparak bencillikten kurtulacağına, iyi bir insan olabileceğine inanmaktadır (Renner, Arnzt ve Leeuw, 2013, s.168). Onay arayıcılık şeması bulunan bireyler ise dış dünyanın kendileri hakkındaki verecekleri onaylara "aşırı" derecede ihtiyaç duymaktadırlar. Kendi isteklerinden ve beğenilerinden çok başka insanların onayına bakarak değerlendirme yapmaktadırlar (Young vd., 2018, s.39).

Karamsarlık şemasına sahip bireyler, neredeyse her şeyi olumsuz yönü ile değerlendirmektedir. Kendilerinin mutluluğu bir türlü yakalamayacaklarına ve yaşam boyu mutsuz olacaklarına inanmaktadırlar (Láng, 2015, s.163). Duyguları baskılama şemasına sahip bireyler, duygularını ve isteklerini yaşantılamaktan ve bunları ifade etmekten kaçınan bir profil çizmektedir. Bu bireyler kendilerini rahat bırakamamakta ve genellikle kontrolcü, katı tavırlar sergilemektedir (Young vd., 2019, s.40). Yüksek standartlar şemasına sahip olan bireyler ise aşırı mükemmeliyetçi bir 
yapıdadırlar. Onlar için her şeyin en iyisi ve en mükemmeli olmak zorundadır. Aksi takdirde o durumu iyi ve yeterli olarak değerlendirmemektedirler (Ehsan ve Bahramizadeh, 2011, s.550).

Şemalar; düşüncelerden, duygulardan, anılardan, duyulardan meydana gelmektedir. Şemalar, en geniş anlamıyla bireylerin dünyasını anlamlandıran ve biçimlendiren en temel yapılar olarak tarif edilebilir. Şema terapideki şema kavramından olumsuz ve uyumsuz şemalar kast edilmektedir (Young vd., 2019, s.27). Şemalar, kısa süreli yöntemlerle değişmesi güç olan yapılardır çünkü birey için tanıdık yapılardır ve uzun yıllardır şemalar yaşamını anlamlandırmaktadır. Birey, şemasının kesin olarak doğru olduğunu kabul etmekte ve şemasına uygun davranışlarda bulunmaktadır. Şemalar, bireyin yaşam standartlarını düşürse de birey için tanıdık yapılar olduğu için birey, şemalardan vazgeçmekte çok zorlanmaktadır (Young vd., 2019, s.29,30).

Bilişsel esneklik, bireyin yeni bir duruma karşı tavırlarını ve düşüncelerini değiştirebilmesi olarak tanımlanmaktadır (Çelikkaleli, 2014, s.347). Bilişsel esnekliği yüksek olan bireyler bu durum karşısında verilebilecek farklı tepkiler olduğunun farkındadır ve gerektiği zaman gereken tepkileri vermektedir. Bu bireyler, bu özellikleri sayesinde birçok yeni fikir üretebilen, atılgan, sorumluluk sahibi ve başarılı olabilmektedirler (Martin ve Anderson, 1998, s.1). Bilişsel esneklik, bireyin kişilerarası ve sosyal ilişkilerinin daha sağlıklı bir hale gelmesine de yardımcı olmaktadır (Kolburan, Eker ve Akdeniz, 2019, s.2,9). Bilişsel esnekliği yüksek olan bireylerin özgüvenlerinin, özsaygılarının daha yüksek olduğu yönünde birçok çalışma yapılmıştır (Bilgin, 2009, s.152).

Depresyon ve kaygı gibi durumlar, çoğunlukla farklı bakış açılarının oluşturulamaması ve katı bir düşünce tarzından kaynaklanmaktadır. Dolayısıyla bilişsel esnekliği yüksek olan bireyler strese karşı daha dayanıklıdır. Depresyona ve kaygıya yakalanma ihtimalleri de daha düşüktür (Deveney ve Deldin, 2006, s.430).

Bilişsel duygu düzenleme, duyguların bilişler (düşünceler) tarafindan düzenlenmesi ve kontrol edilmesi olarak tanımlanabilir (Demirtaş, Özdevecioğlu ve Çapar, 2015, s.169). Bilişsel duygu düzenleme, sadece uyum bozucu duyguların değil uyumlu duyguların da çeşitli stratejilerle şiddetinin azaltılması, arttırılması, düzenlenmesi işlevlerine hizmet etmektedir (Demirci ve Güneri, 2020, s.654). Duygular yaşam açısından çok önemli ve işlevsel olmakla beraber uygun şekilde yönetilemediğinde çeşitli sorunlar ortaya çıkabilmektedir (Duman, Yılmaz, Umunç ve 
İmre, 2019, s.3). Dolayısıyla bilişsel duygu düzenleme stratejilerini iyi bir şekilde kullanabilen bireyler; iş yaşamında, romantik ilişkilerinde, sosyal yaşamında, eğitim hayatında ve diğer birçok alanda daha işlevsel bir tablo sergileyebilmektedir. Yaşamında yeteri kadar duygu düzenleme stratejileri kullanamayan bireyler psikolojik bozukluklara ve strese de daha yatkın olmaktadır. Buna karşın bilişsel duygu düzenleme yetisi yüksek olan bireyler, strese ve psikolojik bozukluklara karşı daha dirençlidir (Erpınar, 2017, s.4; Duy ve Yıldız, 2014, s.24)

Bilişsel duygu düzenlemenin toplam 9 tane alt stratejisi bulunmaktadır. Bunlar şu şekildedir;

1. Kabul etme: Ortaya çıkan olumsuz durumun değiştirilmesinden çok durumun kabul edilmesine yönelik vurgu yapılan bir stratejidir (Wolgast, Lundht, Viborg, 2011: 859).

2. Plan yapmaya yeniden odaklanma: Problem çözme üzerine yoğunlaşan bir duygu düzenleme stratejisidir. Bireyin, olayı değerlendirip uygun adımlar atması olarak da tarif edilebilir (Yeşiltaş, 2020: 23).

3. Olumlu yeniden odaklanma: Başa gelen olumsuz yaşam olayının hep olumsuz yönlerinden bakmak bu şekilde değerlendirmek yerine bu durumun olumlu yönlerini de görmeye çalışmak ve bu şekilde değerlendirmektir (Onat ve Otrar, 2010: 127).

4. Olumlu tekrar değerlendirme: Olumsuz durumları tekrardan ele alıp bu duruma olumlu anlam atfetme stratejisidir (Onat ve Otrar, 2010: 127).

5. Olayın değerini azaltma: Olumsuz olaylara önem verdikçe onun verdiği stres ve duygusal olumsuzluk da o oranda artacaktır. Bu stratejide birey, başına gelen durumun değerini azaltmaktadır (Yeşiltaş, 2020: 23).

6. Kendini suçlama: Bu stratejiyi kullanan birey, kendisini olumsuz durum karşısında kendisini suçlayıcı bir tavır takınmaktadır (Onat ve Otrar, 2010: 127).

7. Diğerlerini suçlama: $\mathrm{Bu}$ stratejiyi kullanan bireyler ise başına gelen olumsuz durum nedeniyle başka insanları suçlayıcı bir tavır takınmaktadır (Garnefski, Kommer, Kraaij, Teerds, Legerstee, Onstein, 2002: 406).

8. Ruminasyon: Olumsuz düşünceleri devamlı olarak kişinin geviş getirircesine düşünmesi olarak tarif edilebilir (Berman, Peltier, Nee, Kross, Deldin, Jonides, 2011: 548). 
9. Yıkıcılık: Yaşanan olumsuz durumu felaketleştirircesine bireyin abartılı bir şekilde yorumlamasıdır (Yeşiltaş, 2020: 23).

Araştırmacılar; yıkıcılık, ruminasyon, diğerlerini suçlama, kendini suçlama stratejilerini uyumlu stratejiler olarak betimlemektedir. Olayın değerini azaltma, olumlu tekrar değerlendirme, olumlu yeniden odaklanma, plan yapmaya yeniden odaklanma ve kabul etme stratejilerini ise uyumsuz stratejiler olarak kabul etmektedir (Martin ve Dahlen, 2005: 1250).

$\mathrm{Bu}$ çalışmanın amacı değişmesi zor ve katı yapısı olan erken dönem uyum bozucu şemalar ile duyguların bilişler yolu ile düzenlenmesi olarak tanımlanan bilişsel duygu düzenleme ve farklı durumlarda düşünce ve davranışları değiştirebilme yetisi olarak tanımlanabilen bilişsel esneklik arasındaki ilişkilerin incelenmesidir. Şemalar, kısa süreli yöntemlerle değiştirilmeleri güç olan yapılardır çünkü şemalar çok erken yaşlardan kökenini almakta ve birey için sarsılmaz ve gerçekçi inanışlar olarak değerlendirilmektedir. Bilişsel esneklik kavramı ise şema kavramının tam tersi bireyin düşünce ve davranışlarında esnek olabilmesini ifade ederken bilişsel duygu düzenleme kavramı da şemaların tersine bireylerin duygularını düşünceleri yolu ile düzenlemesi, denetim altında tutabilmesidir. Dolayısıyla şemaların bilişsel esneklik ve bilişsel duygu düzenleme ile arasında negatif ilişki olduğu, bilişsel esneklik ile bilişsel duygu düzenlemenin de arasında pozitif ilişki bulunduğu düşünülmüştür.

\section{Yöntem}

\subsection{Araştırmanın Modeli}

$\mathrm{Bu}$ araştırma ilişkisel tarama modeline göre yapılmıştır. Bir veya birden fazla değiş̧kenin birlikte değişim varlığını göstermeyi amaçlayan model "ilişkisel tarama modelidir. 


\subsection{Katılımcılar}

Katılımcılar, İstanbul ilinde yaşayan 18 yaş üstü toplam 343 bireyden oluşmaktadır. Katılımcıların \%73.5'i kadın (n=252), \%26.5'i (n=91) erkektir. \%36.7'si (n=126) 18-24 yaş aralığında, \%26.8'i (n=92) 25-29 yaş aralığında, \%18.7'si (n=64) 30-35 yaş aralığında, \%16.9’u (n=58) 36 ve üzeri yaşındadır. Katılımcıların \%54.5’i (n=187) çalışmıyor, \%45.5'i (n=156) çalışıyor. \%37.6'sı ( $\mathrm{n}=129)$ evli, \%60.6'sı (n=208) bekar, \%1.2'si (n=4) diğer medeni durumdandır. Katılımcıların \%8.5'i (n=29) ilkokul mezunu, \%9.3’ü $(n=32)$ ortaokul mezunu, \%24.2’si (n=83) lise mezunu, \%47.8'si (n=164) üniversite mezunu, \%9.9'u (n=34) yüksek lisans ve üzeri mezunudur.

\subsection{Veri Toplama Araçları}

Araştırmada veri toplama aracı olarak; sosyo-demografik veri formu, Young Şema Ölçeği Kısa Form-3 (YŞÖ-KF3), Bilişsel Esneklik Ölçeği (BEÖ), Bilişsel Duygu Düzenleme Ölçeği (BDDÖ) kullanılmıştır.

\subsubsection{Sosyo-Demografik Veri Formu}

Literatür incelendikten sonra araştırmacı tarafından uygun görülen değişkenlerle oluşturulmuştur. Sosyo-demografik veri formu; cinsiyet, yaş, çalışma durumu, eğitim süresi ve medeni durumdan meydana gelmektedir.

\subsubsection{Young Şema Ölçeği Kısa Form-3 (YŞÖ-KF3)}

YŞÖ-KF3, 2009 yılında Soygüt, Karaosmanoğlu ve Çakır tarafından Türkçe’ye uyarlanmıştır. 
Ölçek, 6'lı likert şeklinde 90 sorudan oluşmaktadır. Ölçek 4 şema alanı ve 14 alt şema boyutundan oluşmaktadır.

Kopukluk şema alanında; sosyal izolasyon/güvensizlik, duyguları bastırma, duygusal yoksunluk, Kusurluluk

Zedelenmiş otonomi şema alanında; tehditler karşısında dayanıksızlık, terk edilme, başarısızlık, karamsarlık, bağımlılık

Diğerleri yönelimlilik şema alanında; cezalandırılma ve kendini feda

Yüksek standartlar ve bastırılmışlık şema alanında; onay arayıcılık ve yüksek standartlar şemaları bulunmaktadır (Soygüt, Karaosmanoğlu ve Çakır, 2009: 84).

\subsubsection{Bilişsel Esneklik Ölçeği (BEÖ)}

Çelikkaleli (2014) tarafından Türkçe'ye uyarlanan Bilişsel Esneklik Ölçeği 6'lı likert 12 maddeden oluşmaktadır. Ölçekten alınan puan ne kadar yüksekse bilişsel esneklik düzeyi de o kadar yüksek değerlendirilmektedir. Ölçüt bağıntılı geçerliği Martin ve Rubin (1995) tarafından yapılmıştır.

\subsubsection{Bilişsel Duygu Düzenleme Ölçeği (BDDö)}

Bilişsel Duygu Düzenleme Ölçeği Garnefski, Kraaij ve Spinhoven (2001) tarafından geliştirilmiştir. Ölçek, bireyin zorlayıcı durumlar karşısında kullandığı bilişsel duygu düzenleme stratejilerini ölçmek amaciyla oluşturulmuştur. Ölçekte uyumlu ve uyumsuz alt boyutlar dahil olmak üzere toplam 9 alt boyut bulunmaktadır. BDDÖ, Onat ve Otrar tarafindan Türkçe'ye uyarlanmıştır. 


\subsection{Verilerin Analizi}

Verilerin analizinde kullanılan program SPSS 25'tir. Verilerin analizine geçilmeden önce normallik dağılımı kontrol edilmiştir. İki veya daha fazla değişken arasındaki ilişki için Pearson Korelasyon analizi uygulanmıştır. Kullanılan ölçeklerin ve alt boyutlarının basıklık ve çarpıklık değerlerinin $-2+2$ arasında olduğu tespit edilmiştir. Basıklık ve çarpıklık değerleri aşağıda gösterilmiştir.

\begin{tabular}{llll}
\hline & $N$ & Çarpıklık & Basıklık \\
Duygusal Yoksunluk & 343 & 1.255 & 1.143 \\
Sosyal İzolasyon/Güvensizlik & 343 & 0.835 & 0.335 \\
Kusurluluk & 343 & 1.452 & 1.491 \\
Duyguları Bastırma & 343 & 0.908 & 0.421 \\
İç içe Geçme/Bağımlılık & 343 & 1.375 & 1.729 \\
Terk Edilme & 343 & 1.292 & 1.300 \\
Tehditler Karşısında Dayanıksızlık & 343 & 0.912 & 0.677 \\
Başarısızlık & 343 & 1.379 & 1.782 \\
Karamsarlık & 343 & 0.834 & 0.036 \\
Ayrıcalıklılık/Yetersiz Özdenetim & 343 & 0.157 & -0.522 \\
Kendini Feda & 343 & 0.299 & -0.761 \\
Cezalandırılma & 343 & 0.143 & -0.466 \\
Yüksek Standartlar & 343 & 0.267 & -0.811 \\
Onay Arayıcılık & 343 & -0.088 & -0.769 \\
Kabul Etme & 343 & -0.232 & 0.149 \\
Pozitif Tekrar Odaklanma & 343 & -0.108 & 0.047 \\
Plana Tekrar Odaklanma & 343 & 0.012 & -0.546 \\
Pozitif Yeniden Gözden Geçirme & 343 & -0.322 & 0.021 \\
Bakış Açısına Yerleştirme & 343 & 0.008 & -0.117 \\
Düşünceye Odaklanma & 343 & -0.160 & -0.086 \\
Kendini Suçlama & 343 & 0.443 & 0.425 \\
Yıkım & 343 & 0.218 & -0.810 \\
Diğerlerini Suçlama & 343 & 0.000 & -0.428 \\
Bilişsel Esneklik Ölçeği & 343 & -0.102 & -0.667 \\
\hline
\end{tabular}




\section{Bulgular}

Araştırma için toplanan verilerin analiz sonuçlarından elde edilen bulgular aşağıda gösterilmiştir.

Tablo 2. Katılımcıların Sosyo-Demografik Özelliklere Göre Dağılımı

\begin{tabular}{|c|c|c|c|}
\hline & & $\mathbf{N}$ & $\%$ \\
\hline \multirow[t]{3}{*}{ Cinsiyet } & Kadın & 252 & 73.5 \\
\hline & Erkek & 91 & 26.5 \\
\hline & Toplam & 343 & 100.0 \\
\hline \multirow[t]{5}{*}{ Yaş } & $18-24$ & 126 & 36.7 \\
\hline & $25-29$ & 92 & 26.8 \\
\hline & $30-35$ & 64 & 18.7 \\
\hline & 36 ve üzeri & 58 & 16.9 \\
\hline & Toplam & 340 & 99.1 \\
\hline Kayıр & & 3 & 0.9 \\
\hline Toplam & & 343 & 100.0 \\
\hline Çalışma & Çalışmıyorum & 187 & 54.5 \\
\hline \multirow{2}{*}{ durumu } & Çalışıyorum & 156 & 45.5 \\
\hline & Toplam & 343 & 100.0 \\
\hline Medeni & Evli & 129 & 37.6 \\
\hline \multirow[t]{3}{*}{ durum } & Bekar & 208 & 60.6 \\
\hline & Diğer & 4 & 1.2 \\
\hline & Toplam & 341 & 99.4 \\
\hline Kayıр & & 2 & 0.6 \\
\hline Toplam & & 343 & 100.0 \\
\hline \multirow{6}{*}{ Eğitim süresi } & İlkokul mezunu & 29 & 8.5 \\
\hline & Ortaokul mezunu & 32 & 9.3 \\
\hline & Lise mezunu & 83 & 24.2 \\
\hline & Üniversite mezunu & 164 & 47.8 \\
\hline & $\begin{array}{l}\text { Yüksek lisans (Uzman statüsü) ve } \\
\text { üzeri }\end{array}$ & 34 & 9.9 \\
\hline & Toplam & 342 & 99.7 \\
\hline Kayıр & & 1 & 0.3 \\
\hline Toplam & & 343 & 100.0 \\
\hline
\end{tabular}

Tablo 3: Young Şema Ölçeği ile Bilişsel Esneklik Ölçeği Arasındaki İlişkinin İncelenmesine İlişsin Bulgular

\begin{tabular}{ll}
\hline \hline & Bilişsel Esneklik Ölçeği \\
\hline Duygusal Yoksunluk & $-.273^{* *}$ \\
Sosyal İzolasyon/Güvensizlik & $-.134^{*}$ \\
Kusurluluk & $-.375^{* *}$ \\
Duyguları Bastırma & $-.165^{* *}$
\end{tabular}




\begin{tabular}{ll} 
İç içe Geçme/Bağımlılık & $-.341^{* *}$ \\
Terk Edilme & $-.254^{* *}$ \\
Tehditler Karşısında Dayanıksızlık & $-.178^{* *}$ \\
Başarısızlık & $-.333^{* *}$ \\
Karamsarlık & $-.207^{* *}$ \\
Ayrıcalıklılık/Yetersiz Özdenetim & 0.103 \\
Kendini Feda & -0.048 \\
Cezalandırılma & 0.044 \\
Yüksek Standartlar & 0.095 \\
Onay Arayıcılık & 0.071 \\
\hline
\end{tabular}

${ }^{* *} p<0.01,{ }^{*} p<0.05$ Kullanilan test: Pearson Korelasyon Testi

Tablo 4: Young Şema Ölçeği ile Bilişsel Duygu Düzenleme Ölçeği Arasındaki İlişkinin İncelenmesine İlişkin Bulgular

\begin{tabular}{|c|c|c|c|c|c|c|c|c|c|}
\hline & $\begin{array}{c}\text { Ka } \\
\text { bul } \\
\text { Et } \\
\text { me }\end{array}$ & $\begin{array}{c}\text { Pozitif } \\
\text { Tekrar } \\
\text { Odakla } \\
\text { nma }\end{array}$ & $\begin{array}{c}\text { Plana } \\
\text { Tekrar } \\
\text { Odakla } \\
\text { nma }\end{array}$ & $\begin{array}{l}\text { Pozit } \\
\text { if } \\
\text { Yeni } \\
\text { den } \\
\text { Gözd } \\
\text { en } \\
\text { Geçi } \\
\text { rme }\end{array}$ & $\begin{array}{c}\text { Bakış } \\
\text { Açısına } \\
\text { Yerleşt } \\
\text { irme }\end{array}$ & $\begin{array}{l}\text { Düşünc } \\
\text { eye } \\
\text { Odakla } \\
\text { nma }\end{array}$ & $\begin{array}{c}\text { Kend } \\
\text { ini } \\
\text { Suçla } \\
\text { ma }\end{array}$ & $\begin{array}{c}\text { Yik } \\
\text { Im }\end{array}$ & $\begin{array}{c}\text { Diğerl } \\
\text { erini } \\
\text { Suçla } \\
\text { ma }\end{array}$ \\
\hline $\begin{array}{l}\text { Duygusal } \\
\text { Yoksunlu } \\
\text { k }\end{array}$ & $\begin{array}{l}.16 \\
7^{* *}\end{array}$ & -0.050 & $-.228^{* * *}$ & $.237^{*}$ & -0.084 & $.120^{*}$ & $.266^{*}$ & $\begin{array}{l}.33 \\
3^{* *}\end{array}$ & $.277^{* *}$ \\
\hline $\begin{array}{l}\text { Sosyal } \\
\text { İzolasyon } \\
\text { Güvensizl } \\
\text { ik }\end{array}$ & $\begin{array}{l}.22 \\
7^{* *}\end{array}$ & $-.145^{* *}$ & -0.037 & 0.039 & 0.052 & $.296^{* *}$ & $.267^{*}$ & $\begin{array}{l}.33 \\
6^{* *}\end{array}$ & $.367^{* *}$ \\
\hline $\begin{array}{l}\text { Kusurlul } \\
\text { uk }\end{array}$ & $\begin{array}{l}.28 \\
0^{* *}\end{array}$ & -0.006 & $-.278^{* *}$ & $.335^{*}$ & -0.106 & 0.099 & $.381^{*}$ & $\begin{array}{l}.41 \\
8^{* *}\end{array}$ & $.337^{* *}$ \\
\hline $\begin{array}{l}\text { Duygular } \\
\text { I } \\
\text { Bastırma }\end{array}$ & $\begin{array}{l}.24 \\
1^{* *}\end{array}$ & -0.065 & $-.170^{* *}$ & $.173^{-}$ & 0.001 & $.109^{*}$ & $.328^{*}$ & $\begin{array}{l}.32 \\
5^{* *}\end{array}$ & $.307^{* *}$ \\
\hline $\begin{array}{l}\text { İçiçe } \\
\text { Geçme } \\
\text { Bağımlılı } \\
\text { k }\end{array}$ & $\begin{array}{l}.26 \\
0^{* *}\end{array}$ & 0.032 & $-.118^{*}$ & $\begin{array}{c}- \\
.239^{*}\end{array}$ & -0.032 & $.167^{* *}$ & $.333^{*}$ & $\begin{array}{l}.40 \\
3^{* *}\end{array}$ & $.364^{* *}$ \\
\hline $\begin{array}{l}\text { Terk } \\
\text { Edilme }\end{array}$ & $\begin{array}{l}.20 \\
5^{* *}\end{array}$ & 0.029 & $-.114^{*}$ & $.158^{*}$ & -0.015 & $.216^{* *}$ & $.302^{*}$ & $\begin{array}{l}.39 \\
0^{* *}\end{array}$ & $.378^{* *}$ \\
\hline $\begin{array}{l}\text { Tehditler } \\
\text { Karşısınd } \\
\text { a }\end{array}$ & $\begin{array}{l}.24 \\
9^{* *}\end{array}$ & 0.013 & -0.070 & $.180^{*}$ & 0.092 & $.334^{* *}$ & $.268^{*}$ & $\begin{array}{l}.43 \\
3^{* *}\end{array}$ & $.440^{* *}$ \\
\hline
\end{tabular}




\begin{tabular}{|c|c|c|c|c|c|c|c|c|c|}
\hline \multicolumn{10}{|l|}{$\begin{array}{l}\text { Dayanıksı } \\
\text { zlık }\end{array}$} \\
\hline $\begin{array}{l}\text { Başarısızl } \\
\text { ık }\end{array}$ & $\begin{array}{l}.27 \\
0^{* *}\end{array}$ & -0.034 & $-.167^{* *}$ & ${ }^{-}$ & -0.044 & $.196^{* *}$ & $.305^{*}$ & $\begin{array}{l}.38 \\
4^{* *}\end{array}$ & $.301^{* *}$ \\
\hline $\begin{array}{l}\text { Karamsa } \\
\text { rlık }\end{array}$ & $\begin{array}{l}.33 \\
5^{* *}\end{array}$ & -0.043 & $-.144^{* *}$ & ${ }^{-}$ & 0.076 & $.318^{* *}$ & $.375^{*}$ & $\begin{array}{l}.48 \\
8^{* *}\end{array}$ & $.388^{* *}$ \\
\hline $\begin{array}{l}\text { Ayricalık } \\
\text { lılık } \\
\text { Yetersiz } \\
\text { Özdeneti } \\
\text { m }\end{array}$ & $\begin{array}{c}.11 \\
1^{*}\end{array}$ & 0.083 & 0.029 & 0.027 & 0.057 & $.150^{* *}$ & 0.077 & $\begin{array}{l}.16 \\
0^{* *}\end{array}$ & $.250^{* *}$ \\
\hline $\begin{array}{l}\text { Kendini } \\
\text { Feda }\end{array}$ & $\begin{array}{l}0.0 \\
97\end{array}$ & 0.026 & -0.032 & 0.073 & 0.088 & $.233^{* *}$ & $.155^{*}$ & $\begin{array}{l}.30 \\
0^{* *}\end{array}$ & $.225^{* *}$ \\
\hline $\begin{array}{l}\text { Cezalandı } \\
\text { rılma }\end{array}$ & $\begin{array}{l}.22 \\
7^{* *}\end{array}$ & -0.016 & 0.095 & 0.030 & 0.098 & $.268^{* *}$ & $.230^{*}$ & $3^{* *}$ & $.230^{* *}$ \\
\hline Yüksek & 0.0 & 0.078 & 0.026 & - & 0.040 & 0.104 & $.119^{*}$ & .19 & $.154^{* *}$ \\
\hline $\begin{array}{l}\text { Standartl } \\
\text { ar }\end{array}$ & 71 & & & 0.008 & & & & $2^{* *}$ & \\
\hline $\begin{array}{l}\text { Onay } \\
\text { Arayıcılı } \\
\text { k }\end{array}$ & $\begin{array}{c}0.0 \\
34\end{array}$ & -0.056 & 0.088 & 0.023 & 0.043 & $.168^{* *}$ & 0.066 & $\begin{array}{l}.12 \\
5^{*}\end{array}$ & $.184^{* *}$ \\
\hline
\end{tabular}

Tablo 5: Bilişsel Duygu Düzenleme Ölçeği ile Bilişsel Duygu Düzenleme Ölçeği Arasındaki İlişkinin İncelenmesine Dair Bulgular

\begin{tabular}{ll}
\hline & Bilişsel Esneklik Ölçeği \\
\hline Kabul Etme & -0.098 \\
Pozitif Tekrar Odaklanma & 0.028 \\
Plana Tekrar Odaklanma & $.348^{* *}$ \\
Pozitif Yeniden Gözden Geçirme & $.399^{* *}$ \\
Bakış Açısına Yerleştirme & $.109^{*}$ \\
Düşünceye Odaklanma & 0.067 \\
Kendini Suçlama & $-.128^{*}$ \\
Yıkım & $-.320^{* *}$ \\
Diğerlerini Suçlama & $-.207^{* *}$ \\
\hline
\end{tabular}

$* * p<0.01, * p<0.05$ Kullanilan test: Pearson Korelasyon Testi 


\section{Tartışma}

Araştırma sonuçlarına göre; bilişsel esneklik ile başarısızlık, iç içe geçme, kusurluluk puanları arasında orta düzeyde ve negatif ilişki; sosyal izolasyon, dayanıksızlık, duyguları bastırma, terk edilme, duygusal yoksunluk, karamsarlık ve güvensizlik arasında ise zayıf düzeyde ve negatif ilişki bulunmaktadır. Araştırma yapılırken erken dönem uyum bozucu şemalar ile bilişsel esneklik arasında negatif ilişki bulunacağı düşünülmüştür ve sonuçlar da büyük ölçüde bu hipotezi destekler niteliktedir.

Şemalar; katı, değişmesi zor yapılar olarak tarif edilebilirken (Young vd., 2019, s.62) bilişsel esneklik bir bireyin bir göreve ya da duruma karşı davranışını ya da düşünce sistemini değiştirebilme ve uyarlayabilme kapasitesi olarak tanımlanabilir. Bilişsel esnekliği yüksek olan bireyler rahatlıkla düşünce ve davranışlarını değiştirebilme yeteneğine sahipken düşük bilişsel esnekliğe sahip bireyler farklı durumlarda gerekli düşünce ve tavır değişikliğini yapabilmekte zorlanmaktadırlar (Çelikkaleli, 2014, s.347). Bilişsel esnekliği yüksek olan bireyler, yaşam içerisinde daha uyumlu bir profil çizebilmektedirler. Dolayısıyla bilişsel esneklik ile katı ve değişmesi zor yapısı göz önünde bulundurulduğunda erken dönem uyum bozucu şemalar arasında negatif bir ilişki bulunmasının beklenen bir sonuç olduğu düşünülmektedir.

Başarısızlık şeması bulunan birey, kendisinin başarısız olduğuna inanmakta ve kesin olarak başarısız olacağını düşünmektedir (Renner, Arntz ve Leeuw, 2013, s.168). Bu bireyler başarı ile ilgili esnek bir düşünce yapısına sahip değillerdir. İç içe geçme şeması bulunan bireyler, birisi ile beraber aşırı yakın olmadığı zaman mutlu olamayacağını düşünmekte (Thimm, 2010: 374) ve kendi sınırları ile ilgili çok katı ve olumsuz anlayışa sahip görünmektedir. Kusurluluk şemasında birey, kendisi ile ilgili çok katı ve olumsuz inanışlara sahiptir. Kendisinin kötü, çirkin, istenmeyen bir insan olduğuna inanmaktadır (Faraji ve Güler, 2021, s.405). Sosyal izolasyon şemasına sahip birey, kendisinin diğer insanlardan farklı olduğuna inanmakta (Kim, Lee ve Lee, 2014, s.138) ve dolayısıyla hiçbir gruba aidiyet hissetmemektedir. Diğer insanlar ve kendisi arasında esneklikten uzak, katı bir tavır bulunduğu görülmektedir. Dayanıksızlık şeması bulunan birey, kendisinin başına kötü bir şey geleceği ve kendisinin bununla baş edemeyeceğine inanmaktadır (Young vd., 2019: 42). 
Problem çözebilme kapasitesi ile ilgili katı ve olumsuz bir yapı görülmektedir. Duyguları bastırma şemasındaki birey, olumlu veya olumsuz duygularını bastırması gerektiğine inanmaktadır (Young vd., 2019, s.40). Duygularına ve kendisine karşı sert bir tutum içerisindedir. Terk edilme şeması bulunan bireyler kendilerinin kesin olarak terk edileceğine inandıkları için ilişkilerinde birçok sorun yaşamaktadır (Takebe, 2020: 3). Dolayısıyla ilişkilere dair çok olumsuz ve sıkı inanışlara sahiptirler. Duygusal yoksunluk şeması bulunan birey kendisinin kesin olarak sevilmeyeceğine, ilgilenilmeyeceğine inanmaktadır (Young vd., 2019: 41). Birçok ağır eksen II bozukluğunun altında bu şema yatmaktadır ve bu şemaya sahip bireyler çok katı bir inanışa sahiptir. Güvensizlik şeması, kimseye güvenememe ve herkesin kendisine bir şekilde zarar vereceği inanışı ile karakterizedir (Calvete ve Orue, 2012: 106). Gümüş ve Güler (2018) yaptıkları çalışmada güvenli bağlanma gerçekleştirememiş ve güven duyamayan bireylerin yaşam kalitesinin ciddi oranda olumsuz etkilendiğini ortaya koymuşlardır. Etraftaki insanları gerçekçi ve esnek bir şekilde değerlendirmekte çok güçlük çekilmektedir.

Araştırmaya başlanmadan önce bilişsel duygu düzenleme ile erken dönem uyum bozucu şemalar arasında negatif yönlü bir ilişki bulunacağı düşünülmüş ve araştırma sonuçlarına bakıldığında da büyük oranda bu yönde bulgular elde edilmiştir. Bilişsel duygu düzenleme ölçeğinde uyumlu ve uyumsuz olmak üzere toplam 9 alt strateji bulunmaktadır (Onat ve Otrar, 2010: 127). Dolayısıyla çeşitli kombinasyonlarla ilişkilere bakılmış ve genellikle araştırmanın hipotezini destekleyen bulgulara ulaşılmıştır. Genellikle, bilişsel duygu düzenlemenin uyumlu alt stratejileri ile erken dönem uyum bozucu şemalar arasında negatif bir ilişki bulunurken, bilişsel duygu düzenlemenin uyumsuz alt stratejileri ile erken dönem uyum bozucu şemalar arasında ise pozitif bir ilişki bulunmuştur.

Erken dönem uyum bozucu şemalar duygusal durumlarla oldukça ilintilidir. Bireyler şemaları aktive olacak bir durumla karşılaştıklarında tıpkı çocuklarında deneyimledikleri olumsuz duygusal durumun içerisine girerek $\mathrm{o}$ anda da çocukluğunda verdiği tepkilere benzer tepkiler vermektedirler. Şemalar bilişlerden, anılardan, duygulardan oluşmakta ve bireylerin düşünce yapıları da şemalarına bağlı olarak genellikle çarpıktır (Rafaeli, Bernstein ve Young, 2011). Düşüncelerin çarpık olması da duygusal durumları olumsuz etkileyebilecek bir başka durumdur. Bilişsel duygu düzenleme ise duyguların bilişler yolu ile düzenlenmesi veya şiddetinin gerektiği 
zaman düşürülmesi ve gerektiğinde arttırılması şeklinde tanımlanmaktadır (Demirci ve Güneri, 2020, s.654; Demirtaş vd., 2015, s.169). Dolayısıyla olumsuz duygularla karakterize olan erken dönem uyum bozucu şemaları yüksek olan bireylerin bilişsel duygu düzenleme stratejilerinin düşük olacağı düşünülmektedir. Bu hipotezi destekleyen birçok bulgu elde edilmiştir. Tablo 3'ten bilişsel duygu düzenleme ve erken dönem uyum bozucu şemaların arasındaki ilişkiyi gösteren bulgulara ulaşılabilir. Bu hipotezi desteklemeyen bazı bulgular ise şu şekilde elde edilmiştir;

Kusurluluk ile pozitif yeniden gözden geçirme, karamsarlık ile kabul etme puanları arasında orta düzeyde ve pozitif ilişki vardır.

Duygusal yoksunluk ile plana tekrar odaklanma; duygusal yoksunluk, kusurluluk, duyguları bastırma, terk edilme, dayanıksızlık, başarısızlık, sosyal izolasyon güvensizlik, iç içe geçme bağımlılık, yetersiz öz denetim, cezalandırılma ile kabul arasında zayıf düzeyde ve pozitif ilişki bulunmuştur.

Kusurluluk şeması bulunan bireylerin kendileri ile ilgili çok olumsuz inançları bulunmaktadır. Bu bireyler kendilerinin temelde kötü, istenmeyen, kusurlu bir insan olduğu inancını taşımaktadır (Faraji ve Güler, 2021, s.405). Pozitif yeniden gözden geçirme ise yaşanan durumlara olumlu anlamlar atfetmek olarak tanımlanmaktadır (Yeşiltaş, 2020: 23). Araştırmada erken dönem uyum bozucu şemalar ile bilişsel duygu düzenleme arasında negatif bir ilişki olacağı düşünülmüş fakat uyumlu olan bu alt boyut ile kusurluluk şeması arasında orta düzeyde pozitif ilişki bulunmuştur. Bu sonuçtan şöyle bir yargıya varılabileceği düşünülmektedir; kusurluluk şeması bulunan bireyler kendileri ile ilgili oldukça çarpık ve olumsuz inançlara sahip olmasına rağmen dış dünya ile ilgili daha gerçekçi hatta oldukça olumlu düşünce ve inançlara sahip olabilirler. Bu sonucun çıkmasının buna bağlı olabileceği düşünülmektedir.

Araştırmanın hipotezine en fazla uymuyor gibi görünen bilişsel duygu düzenleme alt boyutu ise kabul alt boyutudur. Bilişsel duygu düzenlemenin alt boyutlarından olan kabul alt boyutu literatürde genellikle uyumlu bir alt boyut olarak geçmektedir (Martin ve Dahlen, 2005, s.1250). $\mathrm{Bu}$ çalışmada ise kabul alt boyutunun erken dönem uyum bozucu şemalarla pozitif yönlü bir ilişkisi olduğu görülmektedir. Kabul stratejisi, başa gelen olumsuz olayların duyguların değişiminden bağımsız olarak kabul edilmesi olarak tanımlanabilmektedir. Kabul alt boyutunu, uyumlu bir strateji olarak değerlendirilebileceği gibi olumsuz bir özellik olarak 
değerlendirilebileceği düşünülmektedir (Wolgast, Lundht, Viborg, 2011, s.859). Başa gelen olumsuz durumlarla baş edebilmek için öncelikle o durumu kabullenmek gerekmektedir fakat kabul edildikten sonra öğrenilmiş çaresizlik durumuna girmek ise olumsuz bir durum olarak görülebilir. $\mathrm{Bu}$ araştırmaya katılan katılımcılar da kabul etme alt boyutu sorularını bu biçimde algılamış olabilecekleri için sonucun bu şekilde çıkmış olabileceği düşünülmektedir.

Bilişsel esneklik ile bilişsel duygu düzenleme arasında ise pozitif yönlü bir ilişki bulunacağı varsayılmıştır. Bilişsel esneklik herhangi bir olaya ya da duruma karşı düşünce ve davranışları değiştirebilme yetisi olarak tanımlanmaktadır (Çelikkaleli, 2014, s.347). Bilişsel yapısını duruma göre şekillendirebilen bir bireyin duygusal olarak da daha olumlu ve dengeli bir yapıda olabileceği düşünülmektedir. Dolayısıyla duyguların bilişler yolu ile düzenlenmesi olarak tanımlanan bilişsel duygu düzenleme stratejilerinin de bilişsel esnekliği yüksek olan bireylerde daha yüksek olabileceği varsayılmaktadır. Literatür incelendiğinde de bu konu ile ilgili yapılan az sayıda çalışma olmasına rağmen bu tür sonuçlara ulaşılmaktadır. Demirci ve Güneri (2020) tarafından bilişsel duygu düzenleme ve bilişsel esneklik ile ilgili yapılan bir araştırmada da bilişsel duygu düzenlemenin uyumlu alt boyutlarının bilişsel esnekliği pozitif yordadığı elde edilmiştir. Küçüker (2016) tarafından yapılan başka bir çalışmada bilişsel esnekliğin bilişsel duygu düzenleme ve yaşam doyumu arasındaki ilişkiyi pozitif yordadığını ortaya koyulmuştur. Güler ve Usluca (2021) yaptıkları bir çalışmada bilinçli farkındalığın yaşam doyumunu arttırdığını bulmuşlardır. Dolayısıyla yaşanan durumların farkında olmak ve bunlara gerekli bilişsel tepkileri verebilmek oldukça önem arz etmektedir. Bu çalışmada da bilişsel duygu düzenlemenin uyumlu alt boyutları ile bilişsel esneklik arasında pozitif bir ilişki bulunurken bilişsel duygu düzenlemenin uyumsuz alt boyutları ile bilişsel esneklik arasında negatif bir ilişki bulunmuştur. Bilişsel esneklik ile kendini suçlama, diğerlerini suçlama, yıkım, bakış açısına yerleştirme arasında negatif ilişki elde edilmişken; uyumlu alt boyutlardan olan plana tekrar odaklanma ve pozitif yeniden gözden geçirme arasında ise pozitif ilişki elde edilmiştir.

Literatür incelendiğinde erken dönem uyum bozucu şemalar, bilişsel esneklik ve bilişsel duygu düzenlemenin birbirleri ile ilişkisinin bulunduğu bir araştırma bulunmadığı görülmüş ve birbirleri ile çok ilişkili görünen bu değişkenlerin ilişkisini inceleyen bir araştırma yapılmaya ihtiyaç duyulmuştur. $\mathrm{Bu}$ araştırmanın hem klinik pratikte klinisyenlere hem de araştırmacılara yol göstermesi açısından önemli olduğu düşünülmektedir. 
Araştırmada değişkenlerin, değerlendirilmesi yalnızca kullanılan ölçme aracı ile sınırlıdır. Araştırmanın bir başka sınırlılığı olarak yalnızca İstanbul'da yaşayan bireylerin çalışmaya dahil edilmesi olabilir.

Bu konu ile ilgili çalışma yapacak araştırmacılara; 18 yaş altı katılımcılarla da bu çalışmayı yapmaları, konuyu daha dar kapsamda tutarak belirli şemalar ve belirli bilişsel duygu düzenleme alt boyutları ile daha fazla detaylandırmaları tavsiye edilmektedir.

\section{Kaynakça}

Berman, M. G., Peltier, S., Nee, D. E., Kross, E., Deldin, P. J., ve Jonides, J. (2011). Depression, rumination and the default network. Social Cognitive and Affective Neuroscience, 6(5), 548-555.

Bilgin, M. (2009). Bilişsel esnekliği yordayan bazı değişkenler. Çukurova Üniversitesi Eğitim Fakültesi Dergisi, 3(36), 142-157.

Cecero, J. J., ve Young, J. E. (2001). Case of silvia: a schema-focused approach. Journal of Psychotherapy Integration, 11(2), 217-229.

Çelikkaleli, Ö. (2014). Ergenlerde bilişsel esneklik ile akademik, sosyal ve duygusal yetkinlik inançları arasındaki ilişki. Eğitim ve Bilim, 39(176), 347-354.

Demirci, O. O., ve Güneri, E. (2020). Bilişsel esnekliğin bilişsel duygu düzenleme üzerindeki etkisi. Uludă̆ Üniversitesi Fen-Edebiyat Fakültesi Sosyal Bilimler Dergisi, 21(39), 651-684.

Demirtaş, Ö., Özdevecioğlu, M. ve Çapar, N. (2015). The relationship between cognitive emotion regulation and job stress: moderating role of social support. Asian Social Science, 11(12), 168-173.

Deveney, C. M., ve Deldin, P. J. (2006). A preliminary investigation of cognitive flexibility for emotional information in major depressive disorder and non-psychiatric controls. Emotion, 6(3), 429-437. 
Duman, N., Yılmaz, S. A., Umunç, Ş. ve İmre, Y. (2019). Üniversite öğrencilerinde duygudurum düzenleme ve öfke. Uluslararası Bilimsel Araştırmalar Dergisi (IBAD), 4(1), 1-9.

Duy, B. ve Yıldız, M. A. (2014). Ergenler için duygu düzenleme ölçeğinin Türkçe’ye uyarlanması. Türk Psikolojik Danışma ve Rehberlik Dergisi, 5(41), 23-35.

Ehsan, H. B., ve Bahramizadeh, H. (2011). Early maladaptive schemas and agreeableness in personality five factor model. Procedia-Social and Behavioral Sciences, 30, 547-551.

Erpınar, Z. (2017). Duygu düzenleme, depresyon ve anksiyete arasındaki ilişkiler: yaş ve cinsiyet farklılıkları. Yüksek lisans tezi, Haliç Üniversitesi, İstanbul.

Ertürk, İ. Ş., ve Kaynar, G. (2017). Kişilik bozukluklarında şema terapi yaklaşımı. Ufuk Üniversitesi Sosyal Bilimler Enstitüsü Dergisi, 12, 97-144.

Garnefski, N., Kraaij, V. ve Spihoven, P. (2001). Negative life events, cognitive emotion regulation and depression", Pers Individ Di, 30, 1311-1327.

Garnefski, N., Van Den Kommer, T., Kraaij, V., Teeders, J., Legerstee, J., ve Onstein, E. (2002). The relationship between cognitive emotion regulation strategies and emotional problems: comparison between a clinical and a nnon-Clinical Sample. European Journal of Personality, 16(5), 403-420.

Güler, K., Gümüş, Z. (2018). Erken dönem uyumsuz şemaların yordayıcı olarak çocukluk çağı travmalarının incelenmesi”, Asos Journal, 81, 379-398.

Güler, K., Usluca, M. (2021). Yetişkin bireylerde bilinçli farkındalık ile yaşam doyumu arasındaki ilişkinin incelenmesi. Uluslararası Anadolu Sosyal Bilimler Dergisi, 1(5), 372-383.

Gümüş Z.., Güler K. (2018). Yetişkin bireylerdeki bağlanma stillerinin demografik özellikleri ve yaşam kaliteleriyle olan ilişkinin incelenmesi”, Asos Journal, 78, 505-521.

Hawke, L. D., Provencher, M. D., ve Parikh, S. V. (2013). Schema therapy for bipolar disorder: A conceptual model and future directions. Journal of Affective Disorders, 148(1), 118-122.

Hayes, A. M., Harris, M. S., ve Carves, C. S. (2004). Predictors of self-esteem variability. Cognitive Therapy and Research, 28(3), 369-385.

Işık, S. (2019). Erken dönem uyumsuz şemalar ile erteleme davranışı arasındaki ilişki: şema terapi modelinde bir inceleme. Yüksek lisans tezi, Şehir Üniversitesi, İstanbul. 
Johnsen, T. J., ve Friborg, O. (2015). The effects of cognitive behavioral therapy as an antidepressive treatment is falling: A meta-analysis. Psychological Bulletin, 141(4), 747.

Kim, J. E., Lee, S. W., ve Lee, S. J. (2014). Relationship between early maladaptive schemas and symptom dimensions in patients with obsessive-compulsive disorder. Psychiatry Research, 215(1), 134-140.

Kolburan, Ş. G., Eker, E., ve Akdeniz, B. (2019). Bilişsel esneklik ve mizah stilleri arasındaki ilişkinin değerlendirilmesi. Türkiye Klinikleri Adli Tıp ve Adli Bilimler Dergisi, 16(1), 1-13.

Küçüker, D. (2016). Affetme, affetmeme, bilişsel esneklik, duygu düzenleme ve yaşam doyumu arasındaki ilişkilerin incelenmesi. Yüksek lisans tezi, Pamukkale Üniversitesi, Denizli.

Láng, A. (2015). Machiavellianism and early maladaptive schemas in adolescents. Personality and Individual Differences, 87, 162-165.

Martin, M. M., ve Anderson, C. M. (1998). The cognitive flexibility scale: three validity studies. Communication Reports, 11(1), 1-9.

Martin, R. C., ve Dahlen, E. R. (2005). Cognitive emotion regulation in the prediction of depression, anxiety, stress, and anger. Personality and Individual Differences, 39(7), 1249-1260.

Onat, O., ve Otrar, M. (2010). Bilişsel duygu düzenleme ölçeğinin Türkçe'ye uyarlanması: geçerlik ve güvenirlik çalışmaları. Marmara Üniversitesi Fakültesi Eğitim Bilimleri Dergisi, 31, 123-143.

Rafaeli, E., Bernstein, D. P. ve Young, J. E. (2011). Schema Therapy: Distinctive Features, New York: Routledge.

Renner, F., Arntz, A., Leeuw, I., ve Huibers, M. (2013). “Treatment for chronic depression using shema therapy. Clinical Psychology: Science and Practice, 20(2), 166-180.

Soygüt, G., Karaosmanoğlu, A., ve Çakır, Z. (2009). “Assessment of early maladaptive schemas: A psychometric study of the Turkish Young Schema Questionnaire-Short Form-3. Turkish Journal of Psychiatry, 20(1), 75-84.

Takebe, M. (2020). Intimate Partner Violence, Anger, and Abandonment Schema in Nonclinical Japanese Undergraduate Students, Japanese Psychological Research, https://doi.org/10.1111/jpr.12286 adresinden 12 Şubat 2021 tarihinde erişildi. 
Thimm, J. C. (2010). Personality and early maladaptive schemas: a five-factor model perspective. Journal of Behavior Therapy and Experimental Psychiatry, 41(4), 373380.

Türkçapar, H. M. (2018). Bilişsel Davranışçı Terapi Temel İlkeler ve Uygulama (13.bs.). İstanbul: Epsilon Yayıncılık.

Wolgast, M., Lundh, L. G., ve Viborg, G. (2011). Cognitive reap praisal and acceptance: an experimental comparison of two emotion regulation strategies. Behaviour Research and Therapy, 49(12), 858-866.

Yeşiltaş, D. E. (2020). Özel eğitime gereksinimi olan çocukların anne babalarının bilişsel duygu düzenleme stratejilerinin evlilik uyumuna etkisinin incelenmesi. Yüksek lisans tezi, İstanbul Aydın Üniversitesi, İstanbul.

Young, J. E., Klosko, J.S. ve Weishaar, M.E. (2019). Şema Terapi (T. V. Soylu, çev.). İstanbul: Litera Yayıncılık. 